\title{
HasanuddinLawReview
}

\section{The Guiding Principles on Business and Human Rights: National Action Plans Toward Corporation Responsibility*}

\author{
Ni Ketut Supasti Dharmawan', Desak Putu Dewi Kasih², I Gede Agus \\ Kurniawan $^{3}$, Putu Aras Samsithawrati ${ }^{4}$ \\ ${ }^{1}$ Faculty of Law, Udayana University, Bali, Indonesia. E-mail: arasswk@yahoo.com \\ ${ }^{2}$ Faculty of Law, Udayana University, Bali, Indonesia. E-mail: dewiksh@ymail.com \\ 3 BPR Gianyar, Bali, Indonesia. E-mail:aguskurniawan2015@gmail.com \\ ${ }^{4}$ Legal Officer, Private Company, Bali, Indonesia, E-mail: arassamsitha@yahoo.com
}

\author{
ARTICLE INFO \\ Keywords: \\ Corporation Responsibility; \\ Government Authorities; The \\ GPs; The National Action \\ Plan \\ How to cite: \\ Dharmawan, N. K. S., \\ Kasih. D. P. D., Kurniawan. \\ I. G. A., \& Samsithawrati, \\ P. A. (2018). The Guiding \\ Principles on Business and \\ Human Rights: National \\ Action Plans Toward \\ Corporation Responsibility, \\ Hasanuddin Law Review, \\ 4(2): 123-145 \\ DOI: \\ 10.20956/halrev.v4i2.1480
}

\begin{abstract}
As a global principal, corporations have the obligation to comply with national and international hard law of human rights, respect soft laws and global standards. The United Nations Guiding Principles on Business and Human Rights (GPs) of 2011 were unanimously endorsed by the Human Rights Council and are respected as a global standard that stipulates that corporations should respect human rights when conducting their business activities. The purpose of this paper is to examine the scope and focus of National Action Plans (NAPs) by comparing the Netherlands NAP on Human Rights (2013) is compared to the UK's updated NAP of 2016 with the aim of providing ideas and good examples of a NAP for Indonesia. This study used normative legal method. It is considered to be a valuable lesson both for developed and developing countries that for practical matters it is highly important to create and implement a NAP for the implementation of the GPs. Fortunately, Indonesia in June 2017 has launched a National Action Plan on Business and Human Rights (NAP). The burden responsibility to carry out the NAP on Business and Human Rights to corporation to be implemented strongly rests on the government authorities both central government and all levels authorities, including the local level, have the duty to implement human rights obligation, including to convince corporations that upholding the GPs will ultimately be to their benefit.
\end{abstract}

Copyright @ 2018 HALREV. All rights reserved.

\section{Introduction}

The global phenomenon of high technology, faster communication and transportation makes the process of mobilization between nations much easier. Along with it, more corporations appear and expand their business internationally with profit maximization

\footnotetext{
* The first draft of this paper was presented at the International Conference on International Trade and Business Law, cooperation between Faculty of Law Airlangga University and Faculty of Law the University Waikato New Zealand, 1920 August 2015 at the Faculty of Law Airlangga University, Surabaya, Indonesia.
} 
as their main goal. There is, however, one issue that is often ignored by those corporations but that is actually of fundamental importance and that is the human rights aspect of business activities. This problem constitutes a global issue.

It is undeniable that the issue of human rights in business activities relating to workers, consumers or societies already exists as a social awareness indicator. ${ }^{2}$ However, there are still many cases of human rights violations happening in the business sector which reflects the lack of corporation responsibility concerning human right issues, especially in preventing and mitigating the adverse human right impacts either through their own activities or as the result of their business relationships with other parties. In the past, one example of a tremendous tragedy of human right violation by corporation is Bhopal case in 1984. ${ }^{3}$ The leak of over than forty tons of the poisonous gas methyl isocyanate from a Union Carbide pesticide plant in Bhopal into the surrounding community had caused nearly 3000 immediate death, 50,000 permanently disabled and subsequently another 15,000 deaths from exposure to the poisonous gas. ${ }^{4}$ The human rights abuses and the negative impacts of corporate conduct from unsafe and bad working conditions, environmental degradation, relocation of local communities, until torture have been criticized as an increased number of human rights abuses involving multinational corporations. ${ }^{5}$ The Exxon Mobil Case is another example of a human rights abuse committed by a corporation. This case was about human rights violations in Indonesia, where the plaintiff claimed that the Indonesian military soldiers - who were hired by Exxon Mobil Corporation at their natural gas facility - physically abused and killed family members who lived in the neighborhood of the corporation, which is in rural Aceh. ${ }^{6}$

The human rights violations related to business continually occurred in Indonesia. Reportedly, corporations were the second largest perpetrator after the police that alleged committed human rights abuses during January-December 2016.7 According to the report that was submitted to the National Commission on Human Rights (Komnas HAM) around 7,188 complained were filled. The highest number of alleged human rights violations were related to police (2290 complaint files), followed by corporations (1,030 complaint files), local government (931 complaints). From those complaints, the most reported are related to alleged violations of the right to welfare $(2,748)$, and the right to obtain justice $(2,697)$. The right to welfare is concerned with issues involving corporations and business activities. 8 Related to business activities, it seems business sector also tend abusing children rights. As reported by Human Rights Watch,

2 Source: Lembaga Studi dan Advokasi Masyarakat. (2015). Bisnis dan HAM. Available online from: http://www.elsam.or.id/list.php?cat=bisnis_dan_hamElang=in [Accessed on May 19, 2015]

3 This was the worst industrial disaster where over 15,000 people were injured and 3,000 people were killed by the blast of Chemical Methyl Isocyanate (MIC) of the Union Carbide Chemical Plant in Bhopal, India. See "Analysis Case Study: Union Carbide/Bhopal". Available online from: http://www.ou.edu/deptcomm/dodjcc/groups/02C2/Union\%20Carbide.htm, [Aaccessed May 19, 2015].

4 Business \& Human Rights Resource Centre, "Union Carbide/Dow Lawsuit (re Bhopal)”, https://businesshumanrights.org/en/union-carbidedow-lawsuit-re-bhopal, accessed 19 May 2015.

5 Schrempf-Stirling, J., \& Wettstein, F. (2017). Beyond guilty verdicts: Human rights litigation and its impact on corporations' human rights policies. Journal of Business Ethics, 145(3), 546.

6 Business \& Human Rights Resource Centre. (2017). "Exxon Mobil Lawsuit (re-Aceh)". Available online from: https://business-humanrights.org/en/exxonmobil-lawsuit-re-aceh,. [Accessed April 9, 2017].

7 Korporasi Masuk Tiga Besar Institusi yang Dilaporkan Paling banyak menyangkut konflik agrarian dan ketenagakerjaan (Corporations as the Big Three Reported Institutions Most concerned with agrarian and labor conflict). Available online from : http://www.hukumonline.com/berita/baca/lt587f60d9b3bbb/korporasimasuk-tiga-besar-institusi-yang-dilaporkan. [Accessed January 18, 2017]. Ibid. 
thousands of children in Indonesia, some just 8 years old, are working in hazardous conditions on tobacco farms. Child tobacco workers are exposed to nicotine, handle toxic chemicals, use sharp tools, lift heavy loads, and work in extreme heat. The work can have lasting consequences for their health and development. Indonesian and multinational tobacco companies buy tobacco grown in Indonesia, but none do enough to ensure that children are not doing hazardous work on farms in their supply chains. ${ }^{9}$

The examples mentioned above only constitute a small number of all the cases that happened in reality. In addition, Iman Prihandono through his study reveals that some cases related to the right of economic, social and culture rights that involving TNCs relatively small were brought to the Indonesian courts, some of the cases: the Lapindo mudflow case, the Newmont divestment of shares case, the Indosat divestment and privatization case, the Freeport contract of work case, and the Palyja-Aetra water supply case. ${ }^{10}$ Actually, many efforts have been made, to bring cases to court in order to end human rights abuses as well as to mitigate and minimize the number of business sectors that have an adverse impact on human rights.

Such efforts aim at the corporations' better understanding of how important it is to respect human rights while performing their business. Basically, by doing good business and respecting human rights, the corporations themselves will gain a positive reputation which will lead to sustainable business. Sustainability can be achieved when corporations maximize their profit and simultaneously respect human rights and act responsibly towards the environment. This will not only be to their own benefit, but it will also to the advantage of a broad range of stakeholders including employees and communities. When conducting their business in such a way, corporations will be acting in accordance with several guidelines such as the Guiding Principles on Business and Human Rights (the GPs), the OECD Guidelines for Multinational Enterprises 2011 which are recommendations for responsible business conduct in a global context that are also related to human rights and good corporate governance issues, ${ }^{11}$ as well as both legal norms and social constructs of Corporate Social Responsibility (CSR).

CSR basically involves the awareness of corporations of human right issues particularly on society and environment. ISO 26000 provides guidance on how business and organizations can operate in a socially responsible way. This means acting in an ethical and transparent way that contributes to the health and welfare of society. ${ }^{12}$ There are many initiatives both at the national and the international level to prevent and mitigate adverse impacts on human right caused by business activities of corporations. One

9 Jessica Helena Wuysang/Reuter. (2016). Indonesia Events of 2016. Human Rights Watch. Available online on https:/ / www.hrw.org/world-report/2017/country-chapters/indonesia. [accessed January 18, 2017]

10 Prihandono, I. (2017). Litigating Economic, Social and Cultural Rights against Transnational Corporations in Indonesian Court. Hasanuddin Law Review, 3(3), 246-262. doi: http://dx.doi.org/ 10.20956/halrev.v3i3.1152.

11 The OECD Guidelines for Multinational Enterprises 2011 provides room for human rights protection specifically under chapter IV concerning Human Rights. In this chapter it is emphasized that States have the duty to protect human rights. Enterprises should, within the framework of internationally recognized human rights, the international human rights obligations of the countries in which they operate as well as relevant domestic laws and regulations. Based on Commentary on Human Rights, it is very clear stated that it draws upon the United Nations Framework for Business and Human Rights "Protect, Respect and Remedy" and is in line with the Guiding Principles for its implementations. See OECD.2015. “OECD Guidelines for Multinational Enterprises”. OECD Publishing. ISBN 978-92-6411541-5 (PDF). p. 31. Available online from: $h t t p: / / d x$.doi.org/10.1787/9789264115415-e [accessed May 19, 2015]

12 ISO 26000 - Social responsibility. Available online from: https://www.iso.org/iso-26000-socialresponsibility.html. [Accessed May 19, 2015] 
example of such global standard is the "Ruggie Framework" which was proposed by John Ruggie in 2008 when he promoted a new policy and conceptual framework as the foundation of business and human rights. ${ }^{13}$ This excellent concept was subsequently included in the United Nations Guiding Principles 2011 on Business and Human Rights (GPs). ${ }^{14}$ In the GPs, John Ruggie stated some guiding principles that would help corporations to implement and respect human rights and decrease the number of human rights violations. ${ }^{15}$. The GPs were unanimously endorsed by the Human Rights Council in its resolution 17/4 of 16 June 2011.16 At least minimum protection of human rights as expressed in the International Bill of Human Rights and fundamental principles in the eight ILO core conventions as set forth in the Declaration on Fundamental Principles and Rights at Work are required in these GPs.

As one global standard that directly regulates the issue of human right and business enterprises' activities, the GPs can indeed be considered as a practical guidance for business activities in the world including in developing countries such as Indonesia. The GPs can be seen as to give a positive impact on corporations if they understand and are aware of the importance of the relationship between respecting human rights and business sustainable development. The Action Plan on Business and Human rights is one of the mechanism to endorse the GPs. Therefore, promoting the Action Plan on Business and Human Rights related to the Ruggie Framework and the GPs is considered as an important agenda that needs to be accepted and implemented in the business sector.

The purpose of this paper is to assess the substance of the Action Plan on Business and Human Rights. The Action Plan plays important role in addressing the human rights issues in respect to business since it serves as a practical guide to implement the GPs. By comparing the Action Plans of the UK and the Netherlands, it may be possible to distil some lessons for other countries such as Indonesia. Indonesia is faced with an increase of the international business sector and that why the country needs to adopt and implement a national Action Plan on Business and Human Rights in order to avoid a negative impact on the population's human rights.

This paper first elaborates The Ruggie Principles be used as a guideline for the national Action Plan. Second, this paper examines the important role of National Action Plan in order to implement the three pillars of the GPs: Protect, Respect and Remedy, showing any lessons to be learned from the Action Plans that have been developed by the UK and the Netherlands. At the end, this paper elaborates the Indonesian National Action Plan on Business and Human Rights, particularly investigates who responsible for the development and implementation of such an Action Plan at the domestic level as well as how to convince international corporations who operate in Indonesia that they should live up to their obligations under the national Action Plan.

13 Sanders, A. (2014). The Impact of the 'Ruggie Framework 'and the United Nations Guiding Principles on Business and Human Rights on Transnational Human Rights Litigation.

14 McPhail, K., \& Adams, C. A. (2016). Corporate respect for human rights: meaning, scope, and the shifting order of discourse. Accounting, Auditing \& Accountability Journal, 29(4), 651

15 Heuvel. Grat., \& Dharmawan. N. K. S., (2014). "Corporate Responsibility and Corporate Crime Control in the Tourism Industry". in Faure. M.G., Dharmawan. N. K. S. \& Arsika. I. M. B. (2014). Sustainable Tourism and Law. The Hague: Eleven International Publishingng, p. 285.

16 United Nations Human Rights Council. (2015) “United Nations Human Rights Office of the High Commissioner, Guiding Principles on Business and Human Rights: Implementing the United Nations "Protect, Respect and Remedy" Framework". Available online from: http://webcache.googleuser content.com/search?q=cache:ZRjJqtZu94cJ:www.ohchr.org/Documents/Publications/GuidingPrinciplesBusines HR_EN.pdf $+\mathcal{E} c d=1 \mathcal{E} h l=i d \mathcal{E} c t=c \operatorname{lnk}$ [Accessed May 19. 2015] 


\section{Method}

This study used normative legal research by employing statute approach, conceptual approach, analytical approach as well as comparative approach. Several primary and secondary national and international legal materials were studied and analyzed qualitatively.

\section{The Ruggie Framework and the Three Pillars of GPs}

\subsection{The Ruggie Framework}

It is important to discuss the history of the GPs in order to get broader view on the above issues. the Universal Declaration of Human Rights will be discussed ${ }^{17}$ followed by the emergence of the Ruggie Framework until recently adopted in the GPs. In the past, it was difficult to find explicit human rights conventions and human rights soft law that regulated corporate responsibility including corporate social responsibility to respect human rights. Currently, under the Ruggie Framework and especially the GPs, the law for corporate responsibility is present. In order to respond to the emerge of GPs for corporate responsibility to human rights, some governments such as Australia, Canada, the United Kingdom, as well as the European Union, have adopted the GPs in their public policies and are hoping others countries will follow suit to encourage corporate human rights disclosure. 18

Theoretically international human rights law is applicable to state. In this context, state has obligation to respect, protect and fulfill human rights. Furthermore, both under the United nations and outside of the United Nations system have been developed in an attempt to impose human rights responsibilities on nonstate actors, these initiatives such as the Organization for Economic Cooperation and Development's Guidelines for Multinational Enterprises (OECD Guidelines), the UN Norms on the Responsibilities of Transnational Corporations and other Business Enterprises with regard to Human Rights (Norms on TNCs) and the UN Global Compact. ${ }^{19}$ Then, through many phases and some mandates, in 2008, John Gerard Ruggie - as the Special Representative of Secretary General (SRSG) on Business and Human Rights - presented a recommendation concerning a "Protect, Respect and Remedy" framework 20 that was unanimously endorsed by the UN Human Rights Council on 16 June 2011.21 Nowadays, the Ruggie Framework is usually elaborated with the GPs.

It cannot be denied that the transnational business sector tends to abuse human rights as mentioned above, such as in Indonesia, cases involving corporations that were reported by the Indonesian Human Rights Commission (Komnas HAM) amounted to 1.119 cases in 2010, 1.068 cases in 2011, and 1.084 cases in 2013. Most of the cases concerned human rights violations in the field of land, labour, racial and ethnic discrimination, environmental issues, right to health, rights migrant workers, right to

17 UN Doc. E/CN.4/Sub.2. /2003/12/Rev.2, 10 December 1948.

18 Dubach, B., \& Machado, M. T. (2012). The importance of stakeholder engagement in the corporate responsibility to respect human rights. International Review of the Red Cross, 94(887), 1047-1068.

19 Moyo, K., \& Liebenberg, S. (2015). The privatization of water services: the quest for enhanced human rights accountability. Human Rights Quarterly, 37(3), 708.

20 Ibid.

21 Ruggie, J. G. (2014). Global governance and "new governance theory": Lessons from business and human rights. Global Governance, 20(1), 5-17. 
education, as well as children's rights and women rights. ${ }^{22}$ In the past, there were many discussions on whether human rights violation by transnational corporations could be sued. Since 1990s the issue of business and human rights has been put on the global policy agenda. ${ }^{23}$ Human rights violations in relation with business activities conducted by corporations are spreading worldwide. Many corporations have emerged and expanded their business abroad, but unfortunately, they do not really take the adverse impact of their business activities on human rights into account. Besides Indonesia, Myanmar is another example of an ASEAN country that is often reported as a venue for human rights abuses that are committed by multinational corporations. Although many efforts were made to mitigate the enormous human rights violations conducted by the business sector, they were all unsuccessful until in 2008 Ruggie presented the concept of the Protect, Respect and Remedy Framework or sometime known as the PRR Framework or Ruggie Framework and subsequently operationalized as Guiding Principles in 2011. This Guiding Principles can be seen as a "global standard of expected business conduct" in avoiding, preventing and mitigating those adverse human rights impacts.

\subsection{The Three Pillars of GPs}

The GPs, as was mentioned earlier, consist of three pillars that are supported by 31 guiding principles. Essentially, the three pillars of GPs are known as the Protect, Respect and Remedy framework in relation with business and human rights. In brief, the first pillar concerns the state's duty to protect human rights, the second is the corporate responsibility to respect human rights, and the third is about access to remedy. Before elaborating those pillars further, it is important to explain what is meant by business and human rights itself. According to John Ruggie, ${ }^{24}$ in a larger crisis of the contemporary governance, he describes business and human rights as microcosm, in which there is a gap between the scope, economic actors and impacts, as well as how societies manage the adverse impact itself.

The State's duty to protect human rights as the first pillar is coupled with two (2) main principles, which are: A) Foundational principles and B) Operational principles. The Foundational principles consist of 2 guiding principles (Principles 1 and 2) while the Operational principles consist of 8 guiding principles (Principles 3-10). The first pillar of the GPs mainly states that states have the duty to protect against human rights abuses within their territory and/or jurisdiction by third parties, including business enterprises, which in this context means corporations. The way in which states need to fulfil their duty is by taking appropriate steps to prevent, investigate, punish and redress the human rights abuses through several instruments such as: legislation, regulations, policies as well as adjudication that is supposed to be effectively regulating it. Regarding the human right abuses conducted by corporations, the state itself is not per se responsible for them; however, states can be responsible, if, for example, the state fails

22 Waagstein, P. R. (2013). "Business and Human Rights in Indonesia : from Principles to Practice". Human Rights Resource Centre (HRRC). Jakarta. the British Embassy. p. 8. See also Komisi Nasional Hak Asasi Manusia, Data Pengaduan Pelanggaran HAM oleh Korporasi. (2013). Human Rights Commission, Data Complaint Data Violation of human rights by the Corporation in 2013.

23 United Nations Human Rights Council. Loc.Cit.

24 John Gerard Ruggie, Loc.Cit. p. 6. 
to carry out appropriate ways to prevent, mitigate and punish with regard to the impact of corporations' human right abuses. ${ }^{25}$

The First Pillar concerning the state duty to protect may be criticized. The state's duty to protect human rights is bound to vary from state to state depending on the human rights obligations that a particular state has taken upon itself. The First Pillar adopts a traditional and conventional approach to the state duty to protect human rights. ${ }^{26}$ Under international law, it is possible for states to choose different systems, whether national or international, to determine how to transform international legal instrument into their domestic legal order. The second pillar is the corporate responsibility to respect human rights that will be more elaborated in the next paragraph. This pillar is also coupled with two (2) principles, namely: A) Foundational principles (Principles 11-15) and B) Operational principles (Principles 16-24). The Operational principles cover wide ranged sub-topics including detailed guiding principles concerning policy commitment of corporations, human rights due diligence that should be carried out by corporations, and remediation that should be provided by corporations when they identify that they have caused or contributed to adverse human rights impacts. However, the foundation of this pillar rest on the principle that essentially state corporations should avoid abusing human rights of others and if they are involved in causing adverse human rights impact then they should address it.

The second pillar of GPs is corporate responsibility to respect human rights. As stipulated in the GPs, the responsibility to respect human rights by corporations is not a legal obligation but for all business enterprises worldwide this is formed as the global standard of expected conduct. ${ }^{27}$ This entails that before a corporation will be labelled as upholding Good Corporate Governance (GCG), it needs to show that it takes its responsibility to respect human rights seriously by implementing this standard wherever the corporation operates when conducting its business activities. The GPs set out minimum internationally recognized human rights standards that need to be respected by corporations as their responsibility under Principle 12. This means that wherever they conduct their business activities at a minimum they need to respect the rights expressed in: 1). The International Bill of Human Rights (consisting of the Universal Declaration of Human Rights and the two main Human Rights Covenants viz. the International Covenant on Civil and Political Rights and the International Covenant on Economic, Social and Cultural Rights); and 2). The principles concerning fundamental rights set forth in the International Labour Organization's Declaration on Fundamental Principles and Rights at Work.

All corporations from every sector, size, ownership, operational context and structure need to respect human rights as included in these instruments in proportional measure depending on some factors such as their size (whether it is a small enterprises, mediumsized enterprises or large enterprises). Although the responsibility is proportional, it fully and equally applies to all corporations. ${ }^{28}$ There are two requirements that need to be fulfilled by the corporations in respecting human rights as their responsibility under this GPs, which are stipulated in Principle 13 GPs: 1). When conducting their own activities, corporations need to avoid causing and contributing to adverse human rights

25 United Nations Human Rights Council, Loc.Cit. p. 7.

26 Backer, L. C. (2015). Moving forward the UN guiding principles for business and human rights: Between enterprise social norm, state domestic legal orders, and the treaty law that might bind them all. Fordham Int'l LJ, 38, p. 457.

27 United Nations Human Rights Council. Op.Cit. p. 13.

28 Ibid. p. 14. 
impact; in case such adverse impact nevertheless does occur, they need to address them; and 2). This also holds true for the adverse human rights impact that are directly linked to a corporations' operations, products or services by their business relationships, even if they have not contributed to such impact, the corporations need to seek to prevent and mitigate it.

Furthermore, with regard to the two requirements, the commentary of Principle 13 elaborates that the word "activities" refers to actions and omissions; and the word "business relationship" refers to relationships with entities, partners, value chains and any other state as well as non-state entity that basically has direct links to its products, services and operations. ${ }^{29}$ Three aspects that corporations need to pay attention to in relation to the responsibility to respect human rights are: 30

1. Their policy commitments concerning human rights;

2. Due diligence of human rights that aims to identify, prevent, mitigate and account their adverse human rights impacts that have occurred; and

3. Any process to provide remediation of their adverse human rights impacts.

From those three aspects, the GPs seems to put most emphasis on human right due diligence, this is due to the fact that the GPs elaborate human rights due diligence in 5 principles (Principle 17-21) while policy commitments and remediation each are only explained in 1 principle (respectively Principle 16 and Principle 22). What is meant by human rights due diligence can be found as three elements in Principle 17 of GPs that basically states: 1) it should cover the adverse human rights impacts caused by or contributed to by corporations through their own activities or that can be directly linked to their services, products or operations; 2) it will vary in complexity depending on the size of the enterprise, the risk involved, and the nature and context of their operations; and 3) it is an on-going process because human rights risks may change over time.

Due diligence as required for the business sector as well as for corporations as part of corporate responsibility of Ruggie's second pillar is actually different from the concept of transactional due diligence such as merger that usually needs to be done only previous to a transaction. In the context of corporate responsibility, Ruggie suggests that human rights due diligence is conducted "on-going". ${ }^{31}$ The reason why on-going human rights due diligence is needed is related to the risk that business enterprises may run while they are doing their business activities. As noted in commentary 17 of the GPs, those human rights risks are understood to be the business enterprise's potential adverse human rights impacts. Therefore, "potential impacts "should be addressed through prevention or mitigation, while "actual impacts" - those that have already occurred should be subject of remediation. ${ }^{32}$ In other words, the impacts of business enterprises when they running their business can be classified as: firstly "actual impacts" which can be solved by remediation, and secondly "potential impacts" which can be tackled by ongoing human rights due diligence through prevention or mitigation.

An important part of the human rights due diligence pointed out by the GPs is that the completion of this due diligence will not automatically and fully erase corporations from their liability towards adverse human rights impacts that have occurred. However, this human right due diligence can be used to address the legal claims against the corporations in certain cases because they can show the public they already took

Ibid.

Ibid. p. 15.

Sanders, A. Op.Cit. p. 13.

32 GPs 17 Commentary. p. 18. 
reasonable steps to avoid those adverse human rights impacts. Therefore, this mechanism can at least help the corporations when they face legal claims. The second pillar of the Ruggie Framework concerns the corporate responsibility to respect addresses to all corporations as well as their affiliates. ${ }^{33}$ It is likely that the scope of the second pillar of the GPs is wider which means that corporations and their affiliates should be well-informed about the norms of the second pillar, including the human rights due diligence with its "on-going" process, in order to create more awareness among them concerning their responsibility to respect human rights.

The question is what corporations should do to identify and asses those adverse human rights impacts that factually happen or potentially could happen? According to Principle 18 of the GPs, they can use independent external and/or internal human rights expertise; they need to join the potential affected groups' and also their stakeholders' meaningful consultation activities. The next aims of human rights due diligence are to prevent and mitigate the adverse human rights impacts. With regard to those aims, corporations should conduct two things, namely: 1) effective integration which means ensure that all levels and functions within one corporation handle such responsibility appropriately as well as ensure the availability of effective responses through the process of good internal decision making, oversight process and proper allocation budgeting; and 2) appropriate action that will depend on several factors, such as: a) the corporation's involvement upon adverse human rights impacts - do they cause or contribute to it? Or are they solely involved in it because such impacts by business relationship have a direct link towards their products, operations or services? b) when addressing the adverse human rights impacts, the extent of their leverage should also be considered.

With regard to human rights due diligence set out in GPs, the next step of this due diligence is corporations should track whether they already gave effective responses or not towards such adverse human rights impacts as well as to track whether the human rights policies within their corporations are already well implemented or not. ${ }^{34}$ After they conduct tracking according to Principle 21 of the GPs, corporation should prepare to report externally, in formal ways, how they address their adverse human rights impacts, especially when the affected stakeholders or parties on behalf of those affected stakeholders raise that concern. It can be stated that related with due diligence the four steps of assessment that should be continually improved are: the actual and potential impacts of business misconduct on human rights, the finding of appropriate measures to address the business impacts on human rights, the effective measures in preventing or mitigating adverse human rights impact, and the publishing of reports concerning the process and result of due diligence conducted by the business enterprise. 35 To conclude, the second pillar of the GPs, as stated under commentary 21, concerns communicating transparency and accountability both to individuals as well as to groups who are especially suffering from the negative impact. The report can be in the form of person meetings, online dialogues and formal reports that may go together with financial and non-financial reports. ${ }^{36}$

33 Jagers, N., \& Rijken, C. (2014). Prevention of Human Trafficking for Labor Exploitation: The Role of Corporations. Nw. UJ Int'l Hum. Rts., 12, 46.

34 GPs 17 Commentary. p. 19.

35 Methven O'Brien, C., \& Dhanarajan, S. (2016). The corporate responsibility to respect human rights: a status review. Accounting, Auditing \& Accountability Journal, 29(4), 542-567.

36 GPs Commentary 21, 24. 
Last but not least is access to remedy as the third pillar of the GPs. Again, this pillar is also coupled with Foundational principle (Principle 25) and Operational principles (Principles 26-31). The Operational principles consist of various sub-topics such as statebased judicial mechanism, state-based non-judicial mechanisms, non-state-based grievance mechanisms and effectiveness criteria for non-judicial grievance mechanisms. When victims are faced with adverse human rights impacts caused by business-related human right abuses, the question arises which remedies are available to them. Indeed, the third provides greater access to effective remedies for the victims by providing both judicial and non-judicial mechanisms.

Based on Commentary 22 of the GPs related to adverse human rights actual impacts, business enterprises should be actively engaged in remediation in cooperation with other actors who contribute to adverse consequences. In some situations, in particular when it is alleged that crimes have been committed, typically the cooperation with judicial mechanisms will be required. ${ }^{37}$ In addition, to facilitate and guarantee that the third pillar "Access for remedy" will work under GP Commentary 25 States must take appropriate steps to facilitate judicial mechanisms as well as other appropriate means. In this context, those affected by human rights abuses should have access to effective remedies that may take the form of apology, restitution, rehabilitation, financial or nonfinancial compensation and punitive sanctions (whether criminal or administrative such as fines), as well as the prevention of harm through for example injunction or guarantee of non-repetition. The GPs also require States to raise public awareness and understanding of remedy mechanisms to ensure that remedies can be accessed by those who suffered the consequences of human rights abuses. ${ }^{38}$

The three pillars of the GPS can be used as the basis to make corporations respect human rights in relation to the current situation where business complexity regarding human rights abuses is occurring more often. Although the existence of the GPs, especially the second pillar on corporate responsibility, is criticized because it is not as strong as the norm of State duty or state obligation that has to be respected under legally binding international law, still the GPs have provided guidance for States, business enterprises and victims of the business sector. They indicate how to mitigate human rights abuses committed by the business sector and how to get remedies. Generally, the three pillars of the GPs are intertwined with each other and they are essential as to avoid, prevent, and mitigate the adverse human rights impacts in relation with business activity. They are seen as an integral part of the global standard of expected business conduct to especially overcome the issues on business and human rights.

\section{Examining the Important Role of a National Action Plan in order to Implement the} Three Pillars of the GPs: Protect, Respect and Remedy

\subsection{The Important Role of National Action Plan}

As understood, there are several international human rights conventions such as the International Covenant on Civil and Political Rights (ICCPR) and the International Covenant on Economic, Social and Cultural Rights (ICESCR) that have already been ratified by developed and developing countries. Although developing countries like

37 GPs Commentary 22, 25.

38 GPs Commentary 25, 27-28. 
Myanmar and Indonesia are criticized as being fragile or even very weak in preventing human rights abuses, these countries have recognized the importance of human rights protection, for example by ratifying the above mentioned international human right conventions and accepting the values of human rights as stipulated in the UDHR. ${ }^{39}$

In order to promote and protect human rights in practical matters at the domestic level, it is not enough to ratify human rights conventions. Obviously, some effective actions are needed to develop human right awareness in practice. Various strategic activities can be done such as arranging meetings, providing information and documentations, disseminating recommendations to concerned parties, as well as monitoring and reporting on the implementation of human rights. These important activities are usually carried out by national human rights institutions. ${ }^{40}$ By implementing several actions as emphasized previously including human rights campaigns, the awareness of human rights protection seems to improve. However, such human rights activities usually do not specifically address corporations. Fortunately, the existence and successfulness to regulate human rights related with business activities and enterprises just came up recently through the GPs in 2011 in international fora, although sometimes they are criticized for being only a global standard of expected business conduct and not hard law.

With the emergence of the GPs in 2011, still the question arises how to make corporations feel responsible for human rights or, in other words, how to make human rights implementation in relation to business become true? Furthermore, who should carry out this important task? By examining the broader mandate, competences and the special status of national human rights institutions - especially the relationship between state and non-state actors at the national level as well as at the international level - it can be considered that national institutions can contribute significantly to the development of the UN "Protect, Respect and Remedy" Framework in practice. Moreover, the UN Human Rights Council welcomed and encouraged national human rights institutions to disseminate and implement the GPs in various ways. ${ }^{41}$

In relation to the important action of disseminating GPs to corporations, the UK and the Netherlands have already undertaken action in order to encourage the business sector to respect human rights. Putting the GPs into practice is an important priority for the Netherlands. They have considered creating an Action Plan to promote the implementation of the GPs. The Netherlands announced its Action Plan on Human Rights in order to implement GPs and it was sent to the Dutch Parliament in December 2013.42 Similarly, the UK Action Plan embodies a fundamental premise of the GPs, the structure of the Guiding Principles known as the State duty to protect, companies respect human rights they must know and show that they do as well as governments and companies provide access for remedy for harm occurred. ${ }^{43}$ Lessons learned concerning the important emergence of a National Action Plan can be adopted from the UK and the

39 Indonesia for example, respectively through Indonesian Act No. 12 of 2005 and Indonesian Act No. 11 of 2005 have ratified ICCPR and ICESCR

40 Haász, V. (2013). The Role of National Human Rights Institutions in the Implementation of the UN Guiding Principles. Human Rights Review, 14(3), 177.

$41 \quad$ Ibid. 177,185.

42 Drafting Group on Human Rights and Business (CDDH-CORP). (2014). National Action Plan of the Netherlands on Business and Human Rights, Council of Europe. p. 2.

43 Ruggie, J. G. (2013). Remarks at UK Government Launch Action Plan for Implementing the UN Guiding Principles. London. Harvard University, Former UN Special Representative for Business and Human rights Institute of Directors, London. p. 2. 
Netherlands in order to bring GPs closer into practice, in developed as well as in developing countries.

\subsection{The Netherlands Action Plan on Business and Human Rights}

The Netherlands started by establishing a working group in order to develop an Action Plan for the national implementation of the GPs. The working group worked on the basis of interviews and consultations to compare the current Netherlands policy with the GPs by involving business sector representation, civil society organizations (CSO) as well as other implementing organizations and groups of experts respectively to identify and to formulate various important ideas on the Action Plan. ${ }^{4}$ In 2013, the Action Plan was presented as the National Action Plan on Human Rights. The official publication "CSR Pays off" was identified as a significant current policy of the Netherlands in order to implement International Social Responsibility (ICSR). This is also in accordance with the OECD Guidelines which seem relevant to the GPs. As we know these non-legally binding instrument aims to engage corporations in the promotion of and respect for human rights.

By examining the Action Plan of the Netherlands, there are five important points that could be used as an example for other countries - including Indonesia - that would like to create an Action Plan. Those are: an active role for the government; policy coherence; clarifying due diligence; transparency and reporting; and the scope of remedies. Every element of this Action Plan likely suits the Netherlands current policy. For example, the first element concerning "an active role for the government" emphasizes the important cooperation of the authorities with the Dutch textile sector. The plan mentions that cooperation is needed to tackle human rights abuses in the clothing industry which is in conformity with the CSR improvement of the clothing sector. Therefore, the OECD guidelines as well as the GPs are used as the guiding principles. ${ }^{45}$ Various important points stipulated in the Action Plan are: the government will conduct a dialogue providing various courses on business ethics including CSR; it will provide grants for workshops to help business enterprises with putting a human rights component in their CSR policies; it will provide training courses for civil servants and other implementing organizations who will carry out the GPs and the OECD guidelines in the business sectors, and the authorities will provide access to remedies.

\subsection{The UK's National Action Plan 2013 and the Updated UK's National Action Plan 2016 on Business and Human Rights}

The UK's NAP seems promising. John Ruggie stated that the UK Action Plan was drafted with the structure of the GPs in mind. In addition, the Plan also emphasizes that UK businesses must respect human rights wherever they operate. Moreover, the Companies Act 2006 expected human rights issues to be clarified in annual reports of businesses. ${ }^{46}$ Besides that, such an Action Plan also encourages the provision of reviews to check the adequacy of human rights practices and of public procurement policies for the UK state-owned or supported enterprises. ${ }^{47}$ It is also necessary to provide in-country

44 Steering Committee for Human Rights and Business (CDDH-CORP). (2014). National Action Plan of the Netherlands on Business and Human Rights. 2nd meeting 12 February-14 February. Council of Europe. Angora-Room G05. p. 2.

45 Ibid. p. 4.

46 John G. Ruggie (2). Loc.Cit.

47 Ibid. 
human rights advice to firms as well as the compliance with the international standard. In order to implement the third pillar concerning remedies, the UK considered that its own provision of judicial remedy options as an important in remedy mix. It seems in line with the UN GPs that actually also emphasize that it is an importance step to reduce various practical barriers related to access to remedies. The UK Action Plan embodies within the UK commitment to protect human rights by helping UK companies understand and manage human rights. Through this Action Plan, a clear message concerning business behavior both in the UK and overseas is sent. 48

As mentioned previously, the UK is the first country that launched a NAP on GPs in 2013. Furthermore, the update of the UK's National Action Plan on Business and Human Rights was published on 12 May 2016. It involved a large number of government departments and it is based on the expectation that it is the continuous duty of the government to protect human rights and responsibility of UK businesses wherever they operate. ${ }^{49}$ The structure of the UK's National Action Plan 2016 is based on the three pillars of the GPs. 50

The structure of the updated National Action Plan consists of an introduction, the state's duty to protect human rights, the government's expectation of businesses, access to remedy for human rights abuses resulting from business activity, and the UK Action Plan implementation and further development. The contents of the update concerns: enumeration of several achievements and actions that have taken since the implementation of the UK's National Action Plan 2013; reflection on its developments at the international level including guidance on implementation as well as other countries' experience; the role of the Government in order to help businesses fulfilling their responsibility to respect human rights as required by the second pillar of the GPs; the role of Government to create a secure, predictable and fair environment for UK companies wherever they operate; and the role of Government to support human rights defenders in relation to their effort to provide remedies for victims of human rights abuses committed by business sectors. ${ }^{51}$

In order to promote the State's Duty to protect Human Rights (First Pillar of GPs). Specifically, the UK's NAP's updated version of 2016 already emphasizes several recommendations that should be followed: 52

a) State to stipulate clearly that business should respect human rights throughout their operations;

b) To enforce and review laws aimed at requiring business enterprises to respect human rights;

c) To ensure that other laws and policies related to business enterprises enable and do not constrain, business respect for human rights;

d) To provide guidance for business enterprises;

48 Business and Human Rights Resource Center. “UK National Action Plan Implementing UN Guiding Principles on Business and Human Rights". Available online from: https://business-humanrights.org/en/uknational-action-plan-implementing-un-guiding-principles-on-business-and-human-rights-0, p. 1.

49 Updated UK National Action Plan on Business \& Human Rights. Available online from : https://businesshumanrights.org/en/uk-govt-publishes-updated-national-action-plan-on-business-human-rights.

50 HM Government. "Good Business Implementing the UN Guiding Principles on Business and Human Rights Updated May 2016," Available online from: https://www.gov.uk/government/uploads/system/uploads/ attachment_data/file/522805/Good_Business_Implementing_the_UN_Guiding_Principles_on_Business_and_H uman_Rights_updated_May_2016.pdf, public sector information licensed under the Open Government License v3.0, 4 .

$51 \quad$ Ibid. p. 2

$52 \quad$ Ibid. p. 6. 
e) To encourage, or require business enterprises to communicate their work to address human rights impacts;

f) To promote respect of human rights amongst business enterprises they contact with;

g) To take addition steps to protect in regard to state owned enterprises and agencies;

h) To support businesses in conflict affected contexts; and

i) To ensure policy coherence across government.

In addition, through the updated UK's NAP it can be understood that beside common law rules, the UK also has specific laws to protect and govern business activities. Therefore, those provisions are expected to be coherent with the UK's NAPs which encourages all business sectors to respect and promote human rights as part of corporate responsibility. Several international conventions on Human Rights have already been ratified by the UK such as: ILO's eight core conventions, the ICCPR, the ICESCR as well as the Convention for the Protection of Human Rights and Fundamental Freedoms (the European Convention or ECHR for short). Meanwhile, remedies for victims of human rights abuses have been provided by the Human Rights Act of 1998. Specific provisions concerning good corporate behavior to respect human rights are stipulated under the UK Bribery Act that is in line with OECD commitments, the Declaration on Fundamental Principles and Rights at Work, the OECD Guideline for Multinational Enterprises, the Company Act of 2006 as well as the Modern Slavery Act of 2015 emphasize that slavery and human trafficking should not take place in its business and supply chains.

In the updated NAP, it is also noted that the government has a commitment to implement the first pillar of the GPs. Some elements of that commitment are: continue to contact and lobby foreign states to support international implementation of the GPs commensurate with other relevant international instruments; work with EU partners to implement the first pillar; ensure that the UK Government procurement rules allow for human rights-related matters to be reflected in the procurement of public goods, works and services; work with the members of the International Code of Conduct Association to establish international monitoring mechanisms; work with Voluntary Principles on Security and Human rights Initiative (VPI); support the Voluntary Guideline on the Responsible Governance of Tenure of Land, Fisheries and Forests in the context of National Food Security; as well as continue supporting human rights defenders working on issues related to business and human rights. Furthermore, several cases related to businesses were inserted on the up dated NAP such as the Modern Slavery Case, the Rana Plaza Case as well as the Nairobi Process. It can be considered that the emerging cases on the NAPs aim to emphasize the stronger commitment of the government to carry out their duty to protect human rights.

In relation to the implementation of the GPs' second pillar on corporate responsibility to respect human rights, the updated NAP clearly stipulates that respect for human rights should be at the heart of a company's core operation. It is not the same as philanthropy or social investment. While implementing the second pillar of the GPs, the UK NAPs also suggest businesses to comply with local laws which may be in compliance with human rights and international human rights principles. In order to encourage companies to have their own human rights policies - including avoiding human rights risks related to the operational activities of their business - the UK Government industry created initiatives including reporting, benchmarking performance and guidance for practical matters. ${ }^{33}$ Several key principles as approaches for UK companies in order to

53 The updated UK's NAP. (2016). p. 19, 14. 
respect human rights in their operational activities are stipulated under the updated NAP. Through this approach the UK NAP suggests companies to: comply with all applicable laws; respect the international human rights legal instruments; determine efforts to honor the principles of international human rights; provide appropriate due diligence policies to identify, prevent and mitigate human rights risks; commit monitoring and evaluating result implementation; consult people who may potentially be affected through business enterprises activities particularly the indigenous peoples and other groups including women and girls; emphasize behavior of business that complies to the UN GPs as well as their supply chains both in the UK and overseas through mechanism contractual arrangement; training; monitoring and capacity building; participate in effective grievance mechanisms in order to bring remedy for those who are victims of adverse human rights impacts committed by business activities; and also participate in annual reporting processes of businesses in order to report their policies, activities and impact as well as human rights issues and risks. ${ }^{54}$ From those efforts taken by the government, it seems that to implement the second pillar of the GPs business enterprises must work together with the government since the government plays important role.

\subsection{The Indonesian National Action Plan on Business and Human Rights}

The Netherlands Action Plan for Business and Human Rights as well as the UK Action Plan mentioned above can be taken into account as good examples for developing countries such as Indonesia. As a member of South East Asia, Indonesia is known as a very rapid development of business enterprises which may potentially abuse human rights with their activities. Therefore, the existence of NAP on Business and Human Rights in Indonesia is really needed in order to mitigate or even minimize the impact of business misconduct on human rights. Indeed, this activity to draft a NAP for Indonesia is in line with the encouragement of the UN Working Group that strongly urges all states to develop, enact and update a national action plan as part of the state's responsibility to protect human rights under the first pillar. ${ }^{5}$

In Indonesia, as recommended by the National Human Rights Commission, it is very urgent for the government to develop a NAP on Business and Human Rights as a vehicle for implementing as well as integrating the GPs into the practical stage. In addition, it is also suggested that the NAP on Business and Human Rights in Indonesia can potentially become the central document and coherent with other national regulations concerning the activities of business enterprises related with human rights. Further collaboration between government and relevant stakeholders is needed to bring the NAP on the practice of business sectors. ${ }^{6}$ Actually in Indonesia, there are various binding legal documents that already exist and seem to be coherent to support the implementation of the GPs such as the Act No. 25 Year 2007 on Investment (Indonesian Investment Law) and the Act No. 40 Year 2007 on Limited Liability Companies (Indonesian Company Law). Although there are no explicit provisions specifying that corporations should have human rights policy commitments, human rights due diligence or remediation for adverse human rights impacts in conducting business activities, neither in the Indonesian Company Law nor in the Indonesian Investment Law, some values of

$54 \quad$ Ibid. p. 21, 14-15.

55 Backer. Op.Cit. p. 472.

56 Kholis, N. (2015). “The Urgency of Developing the National Action Plan on Business And Human Rights in Indonesia, National Human Rights Commission, Available online from: http://elsam.or.id/2015/06/theurgence-of-developing-the-national-action-plan-on-business-and-human-rights-in-indonesia p. 4. 
respecting human rights in conducting business and investments can be detected in several provisions in these instruments. An example of such a value can be found implicitly in Article 74 paragraphs (1), (2), (3) and (4) of the Indonesian Company Law ${ }^{57}$ that specifically obliges companies, especially companies that engages in business in the field and/or related to natural resources, to conduct Corporate Social Responsibility (CSR) or in this Act called Social and Environmental Responsibility. In line with that, with regard to investment activities, the Indonesian Investment Law through Article 15(b) stipulates that every investor basically has an obligation to perform CSR and furthermore, this is coupled with the sanction mentioned in Article 34 upon the failure to perform obligations set out in Article 15.

Why then performing CSR can be considered as reflecting the value of respecting human rights in business activities? It is because CSR has a wide scope. The Triple Bottom Line concept of CSR defined by John Elkington explains that CSR covers the areas of people, the planet and profits -where social and environmental performances are also the elements to create business sustainability that actually go beyond financial performance. ${ }^{58}$ Therefore, it can be considered that corporations are respecting human rights by conducting CSR activities especially in the field of "People responsibility". In line with this - although there is no explicit provision either in the Indonesian Company Law or the Investment Law that regulates that corporations/investors should respect human rights - through the existence of obligations to conduct CSR (especially in the field of social responsibility that closely related with people), it can be considered that those two instruments have already implicitly adopted (although not fully) the principle to respect human rights in business activities, just like in the GPs. Hence, the company or investor can put the making of human rights policy and remediation upon the adverse human rights impacts of their activity as well as human rights due diligence implementation in their CSR agenda, just like the GPs requires corporation to do to respect human rights.

From the above explanation, it can be noted that the Indonesia Company Law and the Investment Law are regulations that specifically regulate matters concerning company and investment but not directly stipulate to respect human rights in conducting business/investment activities. However, aside from the company and investment law areas, to give broader view that Indonesia respects human rights, Indonesia actually has Tourism Law (Act No. 10 of 2009) that directly stipulates the principle of human rights in tourism activities. It can be seen through Article 5 letter (b) that stipulates tourism is performed with the principle that upholds human rights, cultural diversity and local wisdom. It seems promising that the NAP of Indonesia can work coherently both with investment, company and tourism laws as well as other business enterprises related laws. The question then arise in which sector should we start with at the very first place? Of course, the NAP of the GPs should be implemented both in Indonesia State-owned companies or supported enterprises and private corporations where the cores of their

57 Article 74 of Indonesian Company Law stipulates in details that: (1) Company that engages business in the field and/or related to natural resources has obligation to conduct Social and Environmental Responsibility; (2) The Social and Environmental Responsibility as stipulated in paragraph (1) is the obligation of a Company that must be budgeted and calculated as the company's cost and the implementation of which shall be conducted with due observance to appropriateness; (3) Company failing to conduct obligation stipulated in paragraph (1) shall be imposed with sanction in accordance with the provision and regulation; (4) Furthermore, the provisions concerning Social and Environmental Responsibility will be governed through Government Regulation.

58 Wallace, B. (2005). Becoming Part of the Solution: The Engineer's Guide to Sustainable Development. Washington DC. American Council Engineering Companies. p. 37. 
business contain really high risks. The example is the mining sector where this type of business potentially abuses human rights both in the aspects of environmental and human beings such as employees. For this area of business, as mandated by the first Pillar of the GPs "Duty to Protect", the government should pay attention coherently with relevant stakeholders to promote and implement the NAP. However, banking business is also very essential and relevant as the starter sector to immediately implement the NAP of the GPs. Why is it become important? Because as it is understood, currently in the region of ASIA, the economic cooperation has centered largely on Southeast Asian countries through ASEAN initiative ${ }^{59}$ and moreover, the ASEAN Economic Community (the AEC) was also established at the end of 2015 and is anticipated as the seventh largest economy in the world. 60

To support the development of AEC no doubt the banking sector will play an important role. The banking sector has large opportunities to work and cooperate with other corporations to support financial aspects for various modes of business including investment activities. Therefore, the NAP can work smoothly through banking enterprises and, furthermore, the notion of a NAP of the GPs inserted under selfregulatory banking in order to promoting and implementing hand to hand the GPs on Business and Human Rights. In other words, doing good business goes hand in hand with implementing the GPs as a lesson learned from the Netherlands and UK NAPs, it might also work in Indonesia perspective.

\subsection{Who Should Take the Tasks of the Drafting Process and Bring NAPs to be Implemented by the Corporations?}

The implementation of international Human Rights instruments and soft law (Guidelines or Initiatives) including for business sectors needs to be carried out by the responsible parties. By exploring the GPs, the updated UK's NAP as well as the Netherlands NAP for Business and Human Rights, it can be considered that the burden of responsibility strongly rests on the authorities (it means that not only central government but all authorities at all levels, including the local level, have the duty to implement human rights obligation). This is related to the first pillar of the GPs concerning the State's duty to protect human rights related with business activities. In addition, with regard to the second and third pillars of the GPs implementation, the role of the government is still very important. The State has the duty to help enterprises to respect human rights regarding their daily operational activities. In other words, the government needs to make the business sector understand and be aware of its responsibility to respect human rights wherever they operate.

The General Principles of the GPs clearly stipulate that these GPs apply to all States and to all business enterprises, both transnational and others, regardless of their size, sector, location ownership and structure. From the GPs, it can be understood that the responsibility to apply the GPs rests on both States and businesses. This legal obligation first and foremost ensues from the human rights treaties that have been ratified is clearly regulated under the Foundational Principles and Operational Principles of the GPs. To achieve better implementation, the GPs needs to be operationalized and drafted more

59 Chien, V., Godwin, A., \& Ramsay, I. (2016). Cross-border cooperation in bank resolution: A framework for Asia. Sing. J. Legal Stud., 1.

60 Ibid., 2. See also Ghelani, R. N. (2015). "ASEAN Economic Growth to Outdo EU," BBC News 20 April 2015, online BBC News. Available online from: www.bbc.co.uk/news/business-32387376. [Accessed May $17,2016]$ 
concretely under the National Action Plans on Business and Human Rights just like has been done under the NAP of the Netherlands and the updated of NAP of the UK. Regarding who has the task to draft the NAP as understood from the GPs, the Foundational Principles and the Operational Principles of the UN GPs as well as from the Netherlands and UK experiences it should be the Indonesian Government.

As mentioned previously, the UK is the first State that launched a NAP on Business and Human Rights in 2013 and it has already updated it in May 2016. Although it seems not all States have already implemented the UN GPs followed by a NAP, fortunately at ASEAN level, ${ }^{61}$ it was announced that Myanmar and other governments including Indonesia are committed to develop a NAP on business and human rights. ${ }^{2}$ Aung Tun Thet, Economic Advisor to the President of Myanmar emphasized that having a NAP will mobilize the government, the private sector and civil society bringing better future to the country. ${ }^{63}$ At the conference, Michael Addo, Chair of the UN Working Group on Business and Human Rights encouraged Indonesia, Philippines and also Malaysia to develop a National Action Plan on Business and Human Rights. Developing the NAPs is likely very urgent at ASEAN level moreover within the era of ASEAN Economic Community 2016, where the development of liberal business which conducted cross broader may potentially have adverse human rights impact. Therefore, the government hand in hand with the business enterprises should pay more attention and take action.

Nur Kholis, the Chief of National Human Rights Commission in 2015, recommended the government of Indonesia to develop a National Action Plan on Business and Human Rights in order to encourage the integration of the UN GPs into Business and Human Rights and also to harmonize with regulations related to business and human rights. ${ }^{64}$ The emergence of the NAP is expected to be one of the ways to solve the adverse human rights impacts related to business in Indonesia which has become more crucial because human rights abuses related to enterprises are still rampant. As mentioned by Dianto Bachriadi, the commissioner of the Komnas HAM, there were more than 1000 reports received in 2015 by the commission. Such cases are mostly related to companies that are accused of illegally taking over indigenous peoples' and local's lands as well as treating employees unfairly. ${ }^{65}$ It was also reported that the number of companies that comply with human rights principles was very small around $2 \%$ or $3 \% .66$ It is indeed a big challenge for Indonesia to increase the corporate responsibility to respect human rights. Facing many human rights abuses committed by business sector has forced the government and NGOs to work harder. Finally, as published in the Jakarta Post, the chairman of Komnas HAM mentioned that the final version of the action plan has been finished.

61 The ASEAN Next-Gen CSR Forum held in Bali Indonesia from 3-7 February 2015.

62 Business and Human Rights Resource Centre. (2015). "Myanmar and other Govts. Commit to develop National Action Plans on Business \& Human Rights at ASEAN Conference". Available online from : https://business-humanrights.org/en/myanmar-other-govts-commit-to-develop-national-action-plans-onbusiness-human-rights-at-asean-conference?utm_source=Business+\%26 [AccessedMay 17, 2015]. See also ASEAN Next-Gen CSR Forum, Available online from: http://asean-csr-network.org/c/news- $a$ 63 Ibid. resources/newsletter-archive/archive/view/listid-3/mailid-55-acn-may-newsletter\#. [AccessedMay 17, 2015]

64 Kholis. Op. Cit. p. 4.

65 Jong, H. N. (2016). "Indonesia: Human Rights Commission to Launch National Action Plan on Business and Human Rights," the Jakarta Post, Januaryy 20, 2016, Available online from : https://businesshumanrights.org/en/indonesia-to-develop-a-national-action-plan-on-business-human-rights\#c132108. [Accessed March 6,2016]

66 Ibid. 
Furthermore, 16 June 2017 for on the sixth anniversary of the United Nations Human Rights Council unanimously endorsing the UN GPs, Indonesia launched a National Action Plan on Business and Human Rights (NAP) joined a select group of fourteen other nations who had previously published. To draft and finally launched NAP, actually it has been a cumulative effort needed brought on by necessity and involving input from government ministries and related institutions, as well as business groups and civil society. Nur Kholis point out that this has been driven by necessity to return control over human rights affairs to the state rather than individual companies. ${ }^{67}$ For better human rights implementation, it is needed harmonization of regulation that cover comprehensive policy in which both government and business enable to meet their responsibilities under the Guiding Principles including corporate social responsibility that now in Indonesia in several laws have exists based on "mandatory" rather than the „voluntary" principle.

By exploring the GPs, the experience of the UK, the Netherlands experience as well as Indonesia, it is without doubt can be stated that government is the core party that should develop and draft the National Action Plan. Of course, such action should be supported by other related agencies such as Human Rights NGO and related Initiative Forums including all business stakeholders.

\section{Conclusion}

The Action Plan on Business and Human Rights plays important role in addressing the human rights issues in respect to business since it serves as a practical guide to implement the GPs. By comparing the Action Plans of the UK and the Netherlands, some lessons learned can be taken into account for Indonesia to adopt and implement a national Action Plan on Business and Human Rights in order to avoid a negative impact on the population's human rights, in which Indonesia in global contexts is faced with an increase of the international business sector. Fundamentally, the Three Pillars of the GPs: Protect, Respect and Remedy be used as a guideline for National Action Plan (NAP) both the UK and the Netherlands.

In order to operationalize the GPs and the task to improve more concretely the NAP of Indonesia on Business and Human Rights, it should be conducted by the Indonesian Government just like has been done under the NAP of the Netherlands and the updated of NAP of the UK. Therefore, the burden of responsibility strongly rests on the government authorities both central government and all levels authorities, including the local level, have the duty to implement human rights obligation, including carry out the NAP on Business and Human Rights to corporation to be implemented. NAPs constitute vehicles for governments and other stakeholders including the business themselves to work together coherently respecting local laws, national laws (such as the Indonesian Company Law, Investment Law and Tourism Law), as well as international instruments related to business and human rights particularly to minimize, mitigate and even to prevent human right abuses in order to create a sustainable good business environment. Fortunately, by June 2017 Indonesia ready to launch the NAP on Business and Human Rights. More importantly, Myanmar and other governments among the ASEAN countries will also develop NAPs on Business and Human Rights.

67 FIHRRST. (2017). "Indonesia Launches National Action Plan on Business E Human Rights," June 2017, Available online from: https://www.business-humanrights.org/sites/default/files/documents/ Indonesia\%27s\%20NAP\%20Launch.pdf. [Accessed May 202018 ]. 


\section{Acknowledgments}

We would like to thank to the Dean Faculty of Law Udayana University who encourage and support us in this study. With our great honor, we would like also to thank Dr. Ingrid Westendorp from Faculty of Law Maastricht University the Netherlands for her expert advice and encouragement throughout this not easy project.

\section{References}

Books

Bill, W. (2005). Becoming Part of the Solution: The Engineer's Guide to Sustainable Development. Washington DC: American Council Engineering Companies.

Heuvel, G. \& Dharmawan, N. K. S. (2014). "Corporate Responsibility and Corporate Crime Control in the Tourism Industry." in Sustainable Tourism and Law, edited by Faure, M.G., Dharmawan, N.K.S. \& Arsika, I. M. B. The Hague.Eleven International Publishing

Institute for Human Rights and Business. (2014). "From Red Flags to Green Flags: The Corporate Responsibility to Respect Human Rights in High-Risk Countries" in the Corporate Responsibility to Respect Human Rights: Soft Law or Not Law. edited by Deva, S. \& Bilchitz D.United Kingdom. Cambridge University Press.

Wetzel, J. R. M. (2016). Human Rights in Transnational Business: Translating Human Rights Obligations into Compliance Procedures. Springer

\section{Articles in Journals}

Backer, L. C. (2015). Moving forward the UN guiding principles for business and human rights: Between enterprise social norm, state domestic legal orders, and the treaty law that might bind them all. Fordham Int'l LJ, 38, 457.

Chien, V., Godwin, A., \& Ramsay, I. (2016). Cross-border cooperation in bank resolution: A framework for Asia. Sing. J. Legal Stud., 1

Dubach, B., \& Machado, M. T. (2012). The importance of stakeholder engagement in the corporate responsibility to respect human rights. International Review of the Red Cross, 94(887), 1047-1068

Haász, V. (2013). The Role of National Human Rights Institutions in the Implementation of the UN Guiding Principles. Human Rights Review, 14(3), 165-187.

Jagers, N., \& Rijken, C. (2014). Prevention of Human Trafficking for Labor Exploitation: The Role of Corporations. Nw. UJ Int'l Hum. Rts., 12, 46.

McPhail, K., \& Adams, C. A. (2016). Corporate respect for human rights: meaning, scope, and the shifting order of discourse. Accounting, Auditing \& Accountability Journal, 29(4), 650-678.

Methven O'Brien, C., \& Dhanarajan, S. (2016). The corporate responsibility to respect human rights: a status review. Accounting, Auditing \& Accountability Journal, 29(4), $542-567$.

Moyo, K., \& Liebenberg, S. (2015). The privatization of water services: the quest for enhanced human rights accountability. Human Rights Quarterly, 37(3), 691-727.

Nicola, J. \& Rijken, C. (2014). "Prevention of Human Right Trafficking for Labor Exploitation." Nortwestern Journal of Human Rights 12 (1)

Prihandono, I. (2017). Litigating Economic, Social and Cultural Rights against Transnational Corporations in Indonesian Court. Hasanuddin Law Review, 3(3), 246262. Doi: $h t t p: / / d x . d o i . o r g / 10.20956 /$ halrev.v3i3.1152. 
Ruggie, J. G. (2013). “Remarks at UK Government Launch Action Plan for Implementing the UN Guiding Principles". London. Harvard University. Former UN Special Representative for Business and Human rights Institute of Directors.

Ruggie, J. G. (2014). Global governance and "new governance theory": Lessons from business and human rights. Global Governance, 20(1), 5-17.

Sanders, A. (2014). The Impact of the 'Ruggie Framework 'and the United Nations Guiding Principles on Business and Human Rights on Transnational Human Rights Litigation

Schrempf-Stirling, J., \& Wettstein, F. (2017). Beyond guilty verdicts: Human rights litigation and its impact on corporations' human rights policies. Journal of Business Ethics, 145(3).

Veronika, H. (2014). "The Role of National Human Rights Institutions in the Implementation of the Un Guiding Principles." Human Rights Rev 14:165-187.

Waagstein, P. R. (2013). "Business and Human Rights in Indonesia: from Principles to Practice." Human Rights Resource Centre (HRRC). Jakarta. supportted by the British Embassy, Jakarta.

\section{Legal Documents}

International Covenant on Civil and Political Rights (ICCPR)

International Covenant on Economic, Social and Cultural Rights (ICESCR)

National Action Plan of the Netherlands on Business and Human Rights

National Action Plan of the UK on Business and Human Rights

The Guiding Principles on Business and Human Rights

The Law No. 25 of 2007 Concerning Indonesian Investment

The Law No. 40 of 2007 Concerning Indonesian Limited Liability Company

Internet

"Analysis Case Study: Union Carbide/Bhopal". Available online from: http://www.ou.edu/deptcomm/dodjcc/groups/02C2/Union\%20Carbide.htm. [Accessed on May 19, 2015].

"International Guidelines: ISO 26000 on Social Responsibility". Available online from : http://webcache.googleusercontent.com/search?q=cache:QYtQOOoidgwJ:https://www.tuv.c om/media/india/informationcenter_1/systems/Corporate_Social_Responsibility.pdf $+\mathcal{E} c d=1$ $\mathcal{E} h l=i d \mathcal{E} c t=\operatorname{clnk}^{\prime \prime}$ [Accessed May 19, 2015]

"Updated UK National Action Plan on Business \& Human Rights." Available online from : https:// business-humanrights.org/en/uk-govt-publishes-updated-nationalaction-plan-on-business-human-rights. [Accessed May 19, 2015].

ASEAN Next-Gen CSR Forum. Available online from : http://asean-csrnetwork.org/c/news-a-resources/newsletter-archive/archive/view/listid-

3/mailid-55-acn-may-newsletter\#.[Accessed 3 April 2017].

Business \& Human Rights Resource Center. “Union Carbide/Dow Lawsuit (re Bhopal)”. Available online from : https:// business-humanrights.org/en/ union-carbidedowlawsuit-re-bhopal. [Accessed 19 May 2015].

Business \& Human Rights Resoure Centre. (2017). "Exxon mobil Lawsuit (re Aceh)". Available online from : https:// business-humanrights.org/en/exxonmobil-lawsuitre-aceh. [Accessed 3 April 2017].

Business and Human Rights Resource Center. "UK National Action Plan Implementing UN Guiding Principles on Business and Human Rights". Available online from: 
https://business-humanrights.org/en/uk-national-action-plan-implementing-unguiding-principles-on-business-and-human-rights-0. [Accessed 19 May 2015].

Business and Human Rights Resource Centre. "Indonesia to develop a National Action Plan on Business \& Human Rights". Available online from: https://businesshumanrights.org/en/indonesia-to-develop-a-national-action-plan-on-business-humanrights\#c132108.

Business And Human Rights Resource Centre. "Myanmar and other Govts. Commit to develop National Action Plans on Business \& Human Rights at ASEAN Conference". Available online from: https://business-humanrights.org/en/myanmar-other-govtscommit-to-develop-national-action-plans-on-business-human-rights-at-aseanconference? utm_source $=$ Business $+\% 26$. [Accessed 19 May 2015].

FIHRRST. (2017). "Indonesia Launches National Action Plan on Business \& Human Rights," June 2017, Available online from: https://www.businesshumanrights.org/sites/default/files/documents/Indonesia\%27s\%20NAP\%20Launch.pdf. [Accessed May 20 2018].

HM Government. "Good Business Implementing the UN Guiding Principles on Business and Human Rights Updated May 2016". Available online from : https://www.gov.uk/government/uploads/system/uploads/attachment_data/file/522805/Good _Business_Implementing_the_UN_Guiding_Principles_on_Business_and_Human_Rights_ updated_May_2016.pdf. public sector information licensed under the Open Government Licence v3.0. [Accessed 20 May 2016].

Human Rights Watch. "World Report 2015: Events of 2014". Available online from : https://www.hrw.org/id/world-report/2015/country-chapters/268176. [Accessed 19 May 2015].

Kholis, N. (2015). "The Urgence of Developing the National Action Plan on Business And Human Rights in Indonesia, National Human Rights Commission" Available online from: http://elsam.or.id/2015/06/the-urgence-of-developing-the-national-action-plan-onbusiness-and-human-rights-in-indonesia. [Accessed 19 May 2015].

Lembaga Studi dan Advokasi Masyarakat. "Bisnis dan HAM". Available online from : http://www.elsam.or.id/list.php?cat=bisnis_dan_hamElang=in. [Accessed on 19 May 2015].

Naidu, R. G. (2015). “ASEAN Economic Growth to Outdo EU”. BBC News 20 April 2015. Online BBC News. Available online from: www.bbc.co.uk/news/business-32387376. [Accessed 19 May 2015].

National Human Rights Commission the Republic of Indonesia. (2015). “Executive Summary on the Report of Human Right Defender in Indonesia Year 2012-2015 (Ringkasan Eksekutif Laporan Situasi Pembela Hak Asasi Manusia di Indonesia Tahun 2012-2015)". Available online from: www.komnasham.go.id/sites/default/files/ dokumen/water2.pdf. [Accessed May 19, 2015].

O'Brien, C. M. \& Dhananrajan, S. (2015). "The Corporate Responsibility to Respect Human Rights: A status Review, NUS Law Working Paper Series 2015/005." Available online from : http://law.nus.edu.sg/wps. [Accessed May 31, 2015].

OECD . "OECD Guidelines for Multinational Enterprises.” OECD Publishing. Available online from: $h t t p: / / d x$.doi.org/10.1787/9789264115415-e. ISBN 978-92-64-11541-5 (PDF). [Accessed May 19, 2015].

Sanders, A. (2016). "The Impact of the "Ruggie Framework" and the United Nations Guiding Principles on Business and Human rights on Transnational Human Rights Litigation." LSE Working Papers. London School of Economics and Political Science Law Department. Available online from : www.lse.ac.uk/. [Accessed May 9, 2016]. 
United Nations Human Rights Council. “United Nations Human Rights Office of the High Commissioner, Guiding Principles on Business and Human Rights: Implementing the United Nations "Protect, Respect and Remedy" Framework". Available online from: http://www.ohchr.org/Documents/Publications/GuidingPrinciples BusinessHR_EN.pdf $+\mathcal{E} c d=1 \mathcal{E} h l=i d \mathcal{E} c t=\operatorname{lnk}$. [Accessed May 19, 2015].

Newspaper

Jawa Post National Network. "Corporations, The Second Largest Human Rights Abusive in Indonesia." December 11, 2012. Available online from : http:/ / www.jpnn.com/read/2012/12/11/150094/Perusahaan-Pelanggar-HAMTerbesar-Kedua-di-Indonesia. [Accessed May 19 , 2015].

Jong, H. N. (2016). “Indonesia: Human Rights Commissionto Launch National Action Plan on Business and Human Rights." the Jakarta Post. January 20, 2016. Available online from: https://business-humanrights.org/en/indonesia-to-develop-a-national-actionplan-on-business-human-rights\#c132108. [Accessed March 12, 2016]

Case Law

Bhopal case in 1984

Kiobel v Royal Dutch Petroleum Co No 10-1491 (2 February 2012)

Kiobel v Royal Dutch Petroleum Co 569 US (17 April 2013) 